Article received on 31st May 2011

Article accepted on 12th April 2012

UDC: 78.01 ; 78.07 Њумен К.

Lauren Redhead*

University of Surrey

School of Arts

Department of Music and Sound Recording

\title{
RE-PERFORMING THE MATERIAL AND NARRATIVE OF THE POST-WAR AVANT-GARDE
}

\begin{abstract}
Contemporary music which does not fit into the narrative of the post-war avantgarde, but which can be said to belong to the same tradition, is often marginalised by this movement. Through an analysis of the implications of an understanding of material in the context of the avant-garde, and a short investigation into the music of Chris Newman, the validity of the term avant-garde and the use of narrative are critiqued with respect to the exclusion of composers from the forefront of contemporary music practice.
\end{abstract}

Keywords: Contemporary Music, Darmstadt School, Myth, Twentieth Century Canon, Chris Newman

Апстракт: Савремена музика која се не уклапа у наратив послератне авангарде, али за коју се може рећи да припада тој традицији, често је маргинализована у том покрету. Кроз анализу импликација разумевања материјала у контексту авангарде, и кратко истраживање музике Криса Њумена (Chris Newman), валидност термина „авангарда“ и употреба наратива критикују се због изузећа најистакнутијих композитора савремене музичке праксе.

Кључне речи: савремена музика, Дармштатска школа, канон двадесетог века, Крис Њумен

* Author contact information: laurenredhead@gmail.com 
The narrative of the avant-garde has proved one of the most effective instruments of the late twentieth and early twenty-first centuries for including and excluding composers from the perceived forefront of contemporary music. This narrative tells of how, since Schoenberg, music has progressed through a development of material, through integral serialism, to create a late twentieth-century canon of works which continue to develop the pool of material made possible after the emancipation of music from tonality. It is in this development, and no other (such as of technology or social relations), that this narrative locates musical innovation. Its group of innovators are the avant-garde. ${ }^{1}$

In Darmstadt in 2006, Kalus Huber described the avant-garde using a metaphor of two contrasting trees-a rounded tree representing general artistic practice, and a fir tree representing the avant-garde. ${ }^{2}$ For Huber, this metaphor explains the difference between the avant-garde group (to which he also assigned himself) and other artists. ${ }^{3}$ This is a very narrow view of both music and society, since only progression in terms of art is seen to contribute the shape of the tree. It also shows how a narrative is often needed to legitimate the avant-garde, since there is no need to prefer either tree when their individual merits are considered.

Christopher Fox uses his investigation into the Darmstadt myth to legitimate modernism. ${ }^{4}$ The fact that some composers do not fit into this myth is seen to be unimportant-for Fox anti-modernist sentiments do not represent the legitimate arguments that critique it. ${ }^{5}$ Historically, then, modernism creates the twentieth century canon; the possibility that some composers suggest that there is no need for a coherent narrative of the twentieth century is enough reason to deny their legitimacy using the narrative of modernism. It is important to highlight this particular view, and that of Klaus Huber, since it comes from a composer who could be said to fit into the narrative of modernism and the avant garde. Fox's internal view explains why it is necessary for modernism's proponents to perpetuate such a view: self survival.

\footnotetext{
${ }^{1}$ Often a link is made within music between the idea of an avant-garde and modernism. The terms can be used interchangeably, not to refer to their literal meanings but to refer to what could be conceived as an almost self-styled group of composers who place themselves and their tradition at the forefront of the teleological progression of material. I shall here refer to the ideology of this group as 'modernism' and their collective identity as 'the avant-garde'.

${ }^{2}$ The gist of this metaphor is that the fir tree is constantly growing upwards, and thus exploring new territory, whilst the rounded tree grows in many different, disparate, directions, never gaining as much height.

${ }^{3}$ Klaus Huber, Lecture at Darmstadt Summer School, August, 2006.

${ }^{4}$ Christopher Fox, 'Darmstadt and the Institutionalisation of Modernism', Contemporary Music Review, 1 February 2007, 26.1, 115.
}

${ }^{5}$ Fox, $120-122$. 
In another context, Peter Bürger's analysis of the artistic avant-garde could also be applied to the Darmstadt narrative. Bürger claims that the western avantgarde-for my purposes the prominent composers of twentieth-century contemporary music-are re-defining the role of art in bourgeois society. ${ }^{6}$ It is easily possible to consider modernist composers, as well as those who consider themselves disciples of this tradition, as that which Bürger calls the "historical avant-garde. ${ }^{7} \mathrm{His}$ essay concedes that "if it is true that art is institutionalized in bourgeois society, then it does not suffice to make the contradictory structure of this ideology transparent; instead, one must also ask what this ideology may conceal." ${ }^{\prime 8}$ Bürger also notes that, "the total availability of material and forms characteristic of the post avant-gardiste art of bourgeois society will have to be investigated both for its inherent possibilities, and the difficulties it creates, and this concretely by the analysis of individual works." Here, I present the beginning of such an investigation, and show how quickly the mask of ideology falls away to reveal what is concealed by the narrative of the avant-garde.

Bürger's definition of this avant-garde, and also the definition of its members, is based on material. More precisely, the material that is associated most prominently with this group of composers and their music: that which is played out in the concert hall, linked to instrumental technique and organology, and which originates in the perceived history of western music. This 'material' is not neutral, and contains its own history and discourse. This was first identified by Theodor Adorno in Philosophy of Modern Music. ${ }^{10}$ Taken to its logical conclusion, this idea states that all materials can be considered to contain historicity, including instruments and single tones, and by association the historicity of canonization can be said to belong to these materials. This carries with it a perceived authority through association. The supposed progression in the narrative of the avant-garde is imagined to belong to a progression of material when it is at least equally likely that this material has been made to fit the narrative. The authority of the material

\footnotetext{
${ }^{6}$ Peter Bürger, Theory of the Avant-Garde, Michael Shaw (trans.), Theory of History and Literature Volume 4, Minnesota, University of Minnesota Press, 2009, 49.

${ }^{7}$ ibid.

8 ibid. 14.

${ }^{9}$ ibid. 94.

${ }^{10}$ Theodor Adorno, Philosophy of Modern Music, trans.by Anne G Mitchell and Wesley V. Blomster, London, Continuum, 2002, 32-36; 117-118; 213. Discussion of this can also be found in Max Paddison, Adorno's Aesthetics of Music, Cambridge, Cambridge University Press, 1995, 85-86; 149-183, Andy Hamilton, Aesthetics \& Music, London, Continuum, 2007, 170, and Carl Dahlhaus, Schoenberg and the New Music, trans. by Derek Puffett and Alfred Clayton, Cambridge, Cambridge University Press, 1990, 277.
} 
belongs equally, if not more, to its historicity as to its present context, and there is good cause to claim that this is not new but historical.

I do not wish to, and indeed feel that there is no need to, propose an alternative narrative. Instead I am proposing a re-examination of these narratives and of music which focuses on the absence of narrative, and acknowledges the teleological progression of material that is performed in the modernist, Darmstadt, narrative. This is a performative progression since its authority is accepted in each subsequent piece without the potential for its re-examination in the course of the same tradition. If this progression is indeed performative, as I claim it is, composers who can be said to belong to this tradition but not to its narrative could be said to be 're-performing' the material. ${ }^{11}$

I have already mentioned two possible narratives and of course many more could be proposed which include and exclude many different composers. But all narratives can be said to be exclusionary in some way, including those proposed by 'New Musicology'. The avant-garde narrative is, however, the most prevalent, ${ }^{12}$ and is able to alienate composers due to geography (it often concentrates on certain centres e.g. Darmstadt, and certainly north-western Europe); identity (gender, sexuality, ethnicity: there are many ways that the avant garde could be seen to be the preserve of European white men), ideology (acceptance of certain 'truths', such as those about material, are necessary for entry into the group), and social engagement (to be part of the avant garde you must be prepared to accept their modes of engagement e.g. the concert hall, and even particular concert halls). Despite its exclusionary aspects, the curious thing about such a narrative is that many composers still seek to be written in to it. To me, the reason for this seems to be the historical legitimacy that can be sought from such a tradition: once part of the narrative, the artistic, commercial, and indeed 'truth' value of one's music is clearly stated; the historical necessity of one's compositions without doubt.

Musical material is the vehicle through which this is reified. In this respect, many things are 'up for grabs' as a material: form, ${ }^{13}$ space, and time, ${ }^{14}$ as well as

\footnotetext{
${ }^{11}$ William Weber, 'The Intellectual Origins of the Musical Canon in Eighteenth Century England', Journal of the American Musicological Society, Autumn 1994, 47.3, 488-520. Weber's description of a 'performed canon' (489-490) could be seen as an equally relevant description of the formation of a narrative and canon of the music I am addressing.

${ }^{12}$ And can be found in the work of Adorno, in the descriptions that composers give of themselves and their music, in educational institutions, and in scholarly (e.g. Richard Taruskin) and journalistic (e.g. Alex Ross) works of the twentieth century.

${ }^{13}$ Adorno, 2002, 117.

${ }^{14}$ Although the philosophical implications of these supposed by the avant-garde narrative are somewhat dubious. I have discussed this in Lauren Redhead, 'Musical Nonlinearity and the Aesthetics of Space and Time' in ACT - The Revue, 2009, 4, 7-13.
} 
the traditional pitch, rhythm, and gesture which belong to musical thinking preSchoenberg. History itself, however, is not considered an acceptable material and the reason for this lies in the avant-garde myth: the illusion of history is what is perpetuated and performed in the works which rely on this myth for their reception. To consider it a material would be to consider the possibility of an avantgarde which existed outside of the myth itself. Given that history, in this case, can be said to be that which is constructed within the myth of musical modernism, anything falling outside of this myth would fall outside of history. In short, it would not exist. Legitimisation within the historical terms of the avant-garde narrative, for those who accept it, therefore equates with legitimisation of existence.

This is the point at which a modern-postmodern tension can be situated: there is an increasing trend for works which belong to the Darmstadt and avant-garde myths to quote from the tradition that legitimizes them. This seems, by Jonathan Kramer's definition, ${ }^{15}$ to make such works postmodern, but the historicity of these quotations, rather than making the past present, renders their present musical details firmly in the past; the definition of material which they accept necessitates this.

An analysis of this concept is possible by looking at music which is on the edge of the avant-garde: music which is sidelined, but is not considered in direct opposition to the modernist avant-garde project. The questions such pieces pose are: what concessions have been allowed to this music by proponents of the avantgarde myth? What are the similarities and differences between the composers or musics? And in what ways is such music a criticism of the avant-garde narrative of the twentieth century? Such questions highlight the performative quality of material in the music of the twentieth century; as an example analysis I offer the music of Chris Newman. Often described as exiled from the UK, Newman's music has also been described as 'intentionally bad' but is experiencing renewed interest in the UK in recent years, largely because of his nationality. This music can very much be said to perform the material and tradition of the avant-garde whilst concurrently having been allowed no part in their narrative.

The example of Newman's music pertinent here is the piece the reason why I cannot live as a composer in my country is a political one (solo piano, 1984). Although similar conclusions could be drawn from most of Newman's œuvre, this example raises a number of interesting points. One does not have to look far for the historicity present in the material of Chris Newman's works: use of material is the first, and most obvious place this manifests itself in a myriad of recognisable

\footnotetext{
${ }^{15}$ Jonathan D Kramer, 'The Nature and Origins of Musical Postmodenism', in: Judy Lochhead and Joseph Auster (eds.), Postmodern Music, Postmodern Thought, London, Routledge, 2002, 13-26.
} 
and unrecognisable quotations. The reason why opens with an explicit quotation from Sibelius' Symphony No. 5, and of this Newman says, "[it is] the familiar thing [...] I wanted to take something and stretch it as far as I could [...] and stretch the stretchings." 16 This presents an insight into his view of material: there is nothing special about the quotation, only about the result. He describes a compositional process which is inherently constructionist (and therefore modernist) but denies the historicity of the material from the outset. Newman says of material "I don't initially think about music as music, but potentially anything, and the musical material is rock-bottom, grade A1 shit [...] these thoughts get concretized into pieces or paintings or whathaveyou. [sic]"17 However, despite the arbitrariness he claims for his material, it is necessary to reconcile with this the fact that Newman did choose to quote from Sibelius, and it is recognisable. What is the significance of Sibelius in this context? I am inclined to claim that it is exactly the recognizability of the quotation that legitimizes its selection. We must hold onto something and it is made clear that this is our 'way into' the music. As a 'way in' Sibelius's significance in history is eroded, to be replaced with only a significance in the mind of the listener. His authority, and therefore his place in the canon, is eroded. The significance of the canon is eroded. History becomes a material.

The criticism of arrogance which could be levelled against Newman in this act is also negated in the light of the quotations from his song cycle New Songs of Social Conscience (voice and piano, 1990) in the piece song to god (solo organ, 1994). Permitting such a function to a quotation of Sibelius means it must be equally ascribed to Newman's self quotation. There are of course a number of differences: not all listeners may be familiar with Newman's earlier work; even familiar listeners might not be so eager to consider Newman's newer work in opposition to his earlier work; the arbitrariness ascribed to Sibelius cannot be equally given to a quotation of music written by Newman when one would imagine a degree of intentionality when he wrote it. However, even when considered in the context of these three concerns, in the light of his other uses of quotation, this case also points to Newman's recognition of the historicity present in his own work only four years after its composition. If past music is subsumed into an historical tradition that legitimates the present, his own work has become 'up for grabs' as a material equally steeped in historicity as Sibelius's.

In Newman's use of quotation the historical tradition, of which the avantgarde sees itself as a descendant, is very much 'up for grabs' as a material. The sacredness of history preserved in the avant-garde narrative is violated from the

\footnotetext{
${ }^{16}$ Chris Newman, communication with the author, April 2009.

17 ibid.
} 
outset. And yet Newman offers music which is in many ways suitable for, presentable in, and accepted into, the concert hall: the very church of modernism. It deals directly with the instruments through which such a history is mediated: the pianist as virtuoso, the organist as the musical exponent of religion, the composer as authority. The very presentation of the music allows it to make this a 'performative' critique. The use of quotation externalizes the modes of engagement needed to make such a comment: the listener can be picked up and swept along by what Newman calls 'something familiar', unwittingly complicit in the degradation of history from an historical narrative to a material.

This action can be described as self-alienating, on the behalf of the composer himself and those listening. In fact, Newman turns his musical author-critique, a performance of what Barthes and Foucault have put into writing, into a geographical situation. Newman's exile from the UK, alluded to in the title of the reason $w h y$, is in fact a self-imposed exile. His residency outside of his home country of course has political overtones relating to the way music is valued and funded, but geographically represents the distance of the author from the reception of his music once history and the canon, as written into the narrative of the avant-garde, are dispensed with.

And yet Newman's music performs the material of the avant garde. On many levels it continues to perpetuate the same material: the historicity of tradition and the canon; the need to draw upon this; the positioning of oneself at the end of a chain of 'great' composers; the social etiquette of performance situations; these things are enduring in his work. But one is left with the impression that all is not well. Where is the virtuosity in the performace of his works? Where is the tradition of the pianist in a piece which doggedly maintains a strict tempo whilst interrupting each phrase before it reaches its 'climax'? Aside from the treatment of material and history, the modes of engagement through which these are frequently presented become an issue.

When one reads the avant-garde in the terms of the definition of material which they embrace, and in the light of the ideas outlined above, two conclusions are possible: either 'avant-garde' is a label which is not linked to the use of material, and in this case the composers who have been grouped together under this label have been so done entirely accidentally, or the term 'avant-garde' is linked to a definition and use of material which cannot itself be said to be literally avantgarde.

Newman is, of course, not the only example in whose music this paradox is played out. Other composers in whose music the same problem can be readily identified include Johannes Kreidler, David Helbich, Ian H. Power, Simon Katan, and Marianthi Papalexandri-Alexandri. However, these composers are still con- 
sidered to fall within the tradition I claim their music critiques as evidenced by the circles and venues in which this music is performed and disseminated. In the cases of such composers it can be said that there is often a desire from the narrators of the avant-garde to normalize the elements of critique present in their music by subsuming it into the narrative and quietening its non-narrative elements. Such composers and music can then be said to be 'on the fringe' of the avant-garde rather than either avant-garde themselves, or a critique of the tradition of which they have nominally become part. Mauricio Kagel represents an historical example of the quest to normalize such influences: his music presents a vociferous critique of the German new music scene, of which he found himself part, and yet his commentators are quick to find reasons for its lack of validity that come from within the narrative of the avant-garde. More recent interest in the programming of Newman's music is representative of a move away from solely programming concert music by 'dead white guys'. This could be said to be a facet of the desire to normalize contrary narratives, by subsuming them into the concert hall, as described above; recent reviews of Newman's music have focussed on his appearance or his Britishness without offering an engagement with the music on its own terms. ${ }^{18}$

Should one take a literal definition of the term 'avant-garde' then such music which exists on the fringe of contemporary music practice should surely agree with it. But in the context of a critique of an historically aware (in the sense that it renders history collectively more valuable than the present) definition of the avant-garde, which looks in a single direction, chasing a vague notion of 'progress', none of the composers or examples I cite can be acceptable. The linear direction of the avant-garde narrative, although permissive enough to allow many composers and musics into its fringe, will never completely subsume their concerns. These concerns do not look in a single direction but investigate all the facets and implications of concert-hall music. Newman's music, as described here, engages directly with the listener as a member of no specific tradition, rather than as an exponent of a specifically contemporary music tradition, and the inclusivity of such an act denies the perceived (and seemingly welcomed) exclusivity of contemporary music from the point of view of those composers who believe they form, or are believed to form, the avant-garde. Overall, this avant-garde narrative accepts that there is only one 'music'; Newman, and the other composers made reference to, posit that there are 'musics', even when contemplating one piece, and such a position prevents the existence of an avant-garde itself.

\footnotetext{
${ }^{18}$ Ivan Hewitt, 'Chris Newman, Rag Factory, Spitalfields Festival, review,' The Telegraph, 16 June 2010, <http://www.telegraph.co.uk/culture/music/classicalconcertreviews/7833430/ChrisNewman-Rag-Factory-Spitalfields-Festival-review.html> [accessed 12 March 2011] and 'Hear and Now' BBC Radio 3, Broadcast 04 September 2010.
} 
I do not see myself as writing the story of 'the real avant-garde' but showing that the narrative of the avant-garde itself is one which does not have validity, even on its own terms, and that this is made clear in its attitude towards material. I have considered the true definition of 'avant-garde' to be the most literal possible; Zygmunt Bauman extends this literal definition to include a relevance to contemporary society. ${ }^{19}$ This definition is also used by Martin Iddon in his insightful article 'The Dissolution of the Avant-Garde'. ${ }^{20}$ Iddon critiques a narrow definition of postmodernity to reach one which could be considered much more socially relevant than its detractors would like it to be. Rather than a postmodern-avant-garde binary, Iddon uses the social critique of postmodernity to come to the conclusions that "[n]ot originality, but individuality has become the most prized goal [of the avant-garde]. The identification factor, the musical signature, becomes a rather primal territorial marking [...]. In order to achieve this individuality it is actually vital that there be no avant-garde."21

In this context, the performed nature of musical material is key, since it is in its performance that the modes of engagement which allow for the perpetuation of the avant-garde narrative to continue are found. An acceptance of this material in its performance allows innovation to be defined in a way which is so narrow as to allow it only to exist within a certain tradition, and within a certain group within that tradition. Some deviations are of course permitted, as shown, but only with a normalizing acceptance of their critique (it seems to say this, but as we all know...).

Adorno asserted that in the first half of the twentieth century totality had collapsed, writing to Krenek, "When I maintain that atonality is the only possible manner of composing today, it is not because I consider it ahistorically to be 'better,' a handier referential system than tonality. It is rather because I think that tonality has collapsed, that every tonal chord has a meaning we can no longer grasp." ${ }^{22}$ It is perhaps possible that, as a very result of the historicity present within in, at the beginning of the twenty-first century material has collapsed. That is to say that it becomes increasingly historical, and any tradition which accepts material as its vehicle does the same. Iddon makes references to the same point when he says, 'modernity's involvement with the fleeting has been retained; its meaning, or the apparatus through which it acquires its meaning, however, has been excised. ${ }^{23}$

\footnotetext{
${ }^{19}$ Zygmunt Bauman, Postmodernity and its Discontents, New York, New York University Press, 1997, 95.

${ }^{20}$ Martin Iddon,'The Dissolution of the Avant-Garde,' Search Journal for New Music and Culture, Winter 2008, 1.

${ }^{21}$ Iddon, 5.

${ }^{22}$ Theodor Adorno, Letter to Krenek, 1929, in: Hamilton, 2007, 164.

${ }^{23}$ Iddon, 7.
} 
It is necessary, in a music which discards such problems, for material itself to become arbitrary. In many ways, this is the case in the examples I have offered: quoted sources, although we can say what they are, might just as well be anything else. In this respect, a narrative which foregrounds such sources, their history and canon, sidelines music which does not accept this as an authority. Music such as Newman's, in which the authority is eroded, reveals the fallacy of the construction of narrative itself-something which will be continued to be revealed in the very mechanisms which place music such as this on the fringe of contemporary music practice.

\section{REFERENCES}

Adorno, Theodor, Philosophy of Modern Music, Anne G Mitchell and Wesley V. Blomster, trans., London: Continuum, 2002.

Bauman, Zygmunt, Postmodernity and its Discontents, New York, New York University Press, 1997.

Bürger, Peter, Theory of the Avant-Garde, Michael Shaw (trans.), Theory of History and Literature Volume 4, Minnesota: University of Minnesota Press, 2009.

Dahlhaus, Carl, Schoenberg and the New Music, Derek Puffett and Alfred Clayton, trans., Cambridge: Cambridge University Press, 1990.

Fox, Christopher, 'Darmstadt and the Institutionalisation of Modernism', Contemporary Music Review, 1 February 2007, 26.1, 39-52.

Hamilton, Andy, Aesthetics \& Music, London: Continuum.

Kramer, Jonathan D., 'The Nature and Origins of Musical Postmodenism', in: Judy Lochhead and Joseph Auster, eds., Postmodern Music, Postmodern Thought, London, Routledge, 2002, 13-26.

Iddon, Martin, 'The Dissolution of the Avant-Garde,' Search Journal for New Music and Culture, Winter 2008, 1.

Paddison, Max, Adorno's Aesthetics of Music, Cambridge: Cambridge University Press, 1995.

Redhead, Lauren, 'Musical Nonlinearity and the Aesthetics of Space and Time', $A C T-$ The Revue, 2009, 4, 7-13.

Weber, William, 'The Intellectual Origins of the Musical Canon in Eighteenth Century England', Journal of the American Musicological Society, Autumn 1994, 47.3, 488-520. 